\title{
Działalność społeczna i edukacyjna Koła Pań Karaimskich w Haliczu
}

\author{
Anna Sulimowicz \\ Uniwersytet Warszawski, Wydział Orientalistyczny \\ Zakład Turkologii i Ludów Azji Środkowej
}

\section{The Social and Educational Activities of the Karaite Ladies' Association in Halicz}

Summary: For centuries women did not play an active role in the social life of Karaite communities in Poland and Lithuania. It was not until the 1920s that a Karaite women's organisation was founded in Vilnius. Sabina Nowachowiczowa, a school teacher and one of the first Karaim women to receive a formal education, founded the Karaite Ladies' Association in Halicz in 1932. The aim of the organisation was to raise the level of its members' spiritual consciousness, educate them in the fields of faith and Karaim history and language, as well as provide them with general knowledge of the contemporary world in order to enable them to pass on traditional Karaite values to their children. The Association organised excursions, meetings to commemorate eminent Karaite figures, as well as lectures given by local scholars and invited guest speakers. The range of topics was very wide, encompassing everything from the principles of faith and notable works of Karaite literature to excavations in Egypt and the question of Crimean independence. In this paper I have analysed particular activities of the circle based on documents from Nowachowiczowa's archive.

Keywords: Karaites, Karaite women, Halicz Karaite community, Halicz, Sabina Nowachowicz 
Charakterystycznym przejawem karaimskiego życia społecznego i kulturalnego w okresie międzywojennym była działalność organizacji kobiecych. Do lat 30. XX w. udział w nim kobiet był niewielki, ograniczony tradycją sprowadzającą pozycję kobiety do roli matki i żony. Oczywiście, w pewnych warunkach Karaimki mogły prowadzić, i prowadziły, działalność zapewniającą im samodzielność ekonomiczną, lecz były to przypadki niezbyt częste. S. Gąsiorowski w monografii Karaimi $w$ Koronie i na Litwie $w X V$-XVIII wieku wymienia kilka zaledwie postaci takich kobiet pojawiających się w dokumentach źródłowych. Zarządzały nieruchomościami, trudniły się lichwą czy, jak „Salomonowa stara” w latach 1771-1775 należąca do grona siedmiu karaimskich właścicieli szynków w Trokach ${ }^{1}$, prowadziły - czy to samodzielnie, czy wspólnie z męskimi krewnymi - własne lub dzierżawione karczmy.

Do edukacji ogólnie rzecz biorąc kobiety dostępu nie miały, co zresztą tyczyło się nie tylko Karaimów. Uczniami w karaimskiej szkole, gdzie nauczano religii wraz z podstawami liturgii oraz języka hebrajskiego w mowie i piśmie byli wyłącznie chłopcy. Dziewczęta - córki lepiej sytuowanych i wykształconych ojców - mogły się co najwyżej uczyć w domu i to w ograniczonym zakresie $\mathrm{z}$ hebrajszczyzny z reguły poznawały jedynie pismo. Jeszcze w latach 30 . XX w. autor ukrywający się pod pseudonimem Karaucu pisał w „Karaj Awazy”: „Gdyby dziś młoda dziewczyna zapragnęła poznać świętą mowę, mogłaby się i uczyć, ale najpierw musiałby znaleźć się chętny nauczyciel-ochotnik, a nauczyciele nie uczą dziewcząt”" Zdarzały się jednak wyjątki - tenże Karaucu nadmienia, że córka Zachariasiewicza, imienia której jednak nie podaje, „była tak wykształcona, że podczas nabożeństw poprawiała czytających [mężczyzn], jeżeli źle czytali”3.

Dziedziną, w której kobiety, odgrywające w liturgii jedynie rolę biernych obserwatorek, mogły wyjść poza krąg domu oraz rodziny i udzielać się społecznie, pozostawała tradycyjnie działalność dobroczynna. Imiona Karaimek spotykamy na listach różnego rodzaju składek i datków na cele religijne i społeczne. Na przykład w inwentarzu kienesy karaimskiej w Łucku znaleźć można imiona licznych donatorek różnego rodzaju sprzętów, ozdób i tkanin.

1 S. Gąsiorowski, Karaimi $w$ Koronie i na Litwie $w$ XV-XVIII wieku, Kraków-Budapeszt 2008, s. 360.

2 Karaucu, Unutkan ribbimiz, „Karaj Awazy” 1932, z. 1 (3), s. 20. Zob. też Zapomniany nauczyciel, przeł. A. Sulimowicz, „Awazymyz” 2006, z. 2 (13), s. 15.

3 Ibidem. Z zichronot w rękopisie nr inw. JSul.I.15 wynika, że córka Szałoma Zachariasiewicza miała na imię Rivka.

4 Inwentarz wyposażenia kienesy sporządzony 28 kwietnia 1883 r. Archiwum Gminy Karaimskiej w Łucku, nr. inw. JSul.VII.22.03. 
Choć na przełomie XIX i XX w. nasiliły się procesy emancypacyjne, zmiany statusu społecznego kobiet w społecznościach karaimskich następowały nader powoli i opornie. Wynikało to nie tylko z peryferyjnego położenia skupisk karaimskich, czy ich hermetyczności i obyczajowego konserwatyzmu, lecz także z faktu, iż emancypacja kobiet w sferze zawodowej dotyczyła przede wszystkim skupionej w miastach klasy średniej, do której należał jedynie ułamek populacji karaimskiej. Dodatkowo w skupiskach znajdujących się na terenie zaboru rosyjskiego (Troki, Wilno, Poniewież) edukacja dziewczynek była utrudniona ze względu na braku powszechnego obowiązku szkolnego. W nieco lepszej pod tym względem sytuacji znajdowały się halickie Karaimki, w Galicji bowiem Ustawa o zakładaniu i utrzymywaniu publicznych szkół ludowych oraz obowiązku posyłania do nich dzieci, uchwalona 25 maja 1873 r. przez sejm krajowy w oparciu o postanowienia państwowego normatywu szkolnego z 1869 r., objęła nauczaniem wszystkie dzieci bez względu na płeć od 6 do 12 roku życia. Otworzyło to drogę do zdobywania formalnego wykształcenia przez karaimskie dziewczęta z pokolenia urodzonego na przełomie lat 70. i 80. XIX w., o czym będzie jeszcze mowa dalej.

Po pierwszej wojnie światowej i odzyskaniu przez Polskę niepodległości, mimo postępującej emancypacji zawodowej kobiet i powszechniejszego dostępu do oświaty, jak też uzyskania przez kobiety praw wyborczych (Dekret Naczelnika Państwa z 28 listopada 1918 roku przyznawał czynne i bierne prawo wyborcze wszystkim obywatelom bez względu na płeć), oficjalny status kobiety w obrębie karaimskiej społeczności nie uległ większym zmianom. Wśród spornych kwestii, jakie w połowie lat 20. pojawiły się podczas prac nad przygotowaniem ujednoliconych statutów poszczególnych gmin i tymczasowych przepisów regulujących stosunek rządu do Karaimskiego Związku Religijnego, był udział kobiet w wyborach osób duchownych. Stał się on przedmiotem dyskusji podczas konferencji przedstawicieli organizacji karaimskich, która odbyła 30 listopada 1924 r. w Wilnie. „Ortodoksi z Trok zajęli stanowisko zdecydowanie negatywne, powołując się na względy rzekomo dogmatyczne” - podano w relacji ze spotkania zamieszczonej w „Myśli Karaimskiej”. Za przyznaniem praw kobietom optowali przedstawiciele gminy halickiej, wspierani początkowo przez Karaimów z Wilna. Ci jednak wkrótce zmienili front, stwierdzając ustami swego reprezentanta, Emanuela Kobeckiego, że „nie przywiązują większej wagi do tej kwestii, godząc się z punktem widzenia troczan, którzy wciąż wypowiadają

$5 \quad Z$ konferencji przedstawicieli organizacyj karaimskich (dnia 30 listopada 1924 r.), „Myśl Karaimska” 1925, z. 2, s. 35. 
się przeciw uprawnieniom kobiet". Ostatecznie Karaimki zostały wyłączone z udziału w wyborach hachana i hazzanów - artykuł 28. Statutu Karaimskiego Związku Religijnego stwierdzał, że „członkami ogólnego zebrania karaimskiej gminy wyznaniowej są wszyscy mężczyźni, obywatele polscy, wyznania karaimskiego, mający ukończonych lat 21"7.

Nie przeszkodziło to niektórym paniom, niezamężnym, posiadającym także wyższe wykształcenie, angażować się w działalność karaimskich organizacji społecznych. W skład zarządu Wileńskiego Stowarzyszenia Karaimów, które powstało w 1921 jako organizacja kulturalno-oświatowa i dobroczynna, a w 1923 r. stanowiło nawet przez pewien czas organ samorządu gminnego zagwarantowany mniejszościom wyznaniowym postanowieniami konstytucji marcowej, weszły Lidia Szole (Szolówna) i Zofia Łopattówna, a po zmianie jego składu w październiku 1923 r. Ksenia Abkowicz ${ }^{8}$. Nie piastowały w nim jednak żadnych ważniejszych stanowisk ani funkcji.

Polem, które pozostawało otwarte dla działalności kobiet, pozostawała przede wszystkim jednak wspomniana wcześniej dobroczynność, dbałość o wystrój domu modlitwy i wspieranie działań kulturalnych.

Po pierwszej wojnie światowej w Trokach i Wilnie działał Komitet Pań pomocy niezamożnym Karaimom, zaopatrujący materialnie osoby powracające z ewakuacji. Aktywnie działała w nim Raisa z Pileckich Abkowiczowa (1879-1925), żona Aleksandra, skarbnika (gabbaja) gminy wileńskiej. Jeszcze przed wojną udzielała się ona społecznie w Kole Młodzieży Karaimskiej, którego była współzałożycielką i prezeską ${ }^{9}$.

Trudno powiedzieć, czy „Komitet pań”, który w porozumieniu z ułłu hazzanem Szemają Firkowiczem i Zarządem Duchownym ukonstytuował się w $1931 \mathrm{r}$. w Trokach ${ }^{10}$, był nową organizacją, czy też reaktywacją dawnego Koła, które po śmierci R. Abkowiczowej i wobec ustabilizowania się sytuacji powracających z tzw. bieżenstwa mogło ograniczyć albo wręcz zawiesić swą działalność. Pod przewodnictwem żony ułf hazzana, Zofii Firkowicz, miejscowe gospodynie (żona prezesa trockiej gminy Nadzieja Zajączkowska, Nadzieja Nowicka, Stella Szpakowska, Kamila Nowicka, Kamila Zajączkowska, Anna Mickiewicz

6 Z walnego zgromadzenia w Trokach w dniu 18 stycznia 1925 r., „Myśl Karaimska” 1925, z. 2, s. 40.

7 Statut Karaimskiego Związku Religijnego w Rzeczypospolitej Polskiej, Dz.U. z 1936 r., nr 72, poz. 518.

$8 \quad Z$ Wileńskiego Stowarzyszenia Karaimów, „Myśl Karaimska” 1924, z. 1, s. 24.

9 Z karty żałobnej, „Myśl Karaimska” 1925, t. 1, z. 2, s. 47.

10 Biblioteka Litewskiej Akademii Nauk (dalej: BLAN), sygn. f. 301-233, k. 195. 
i inne) organizowały świąteczne zabawy, uroczystości jubileuszowe i wycieczki, zbierały fundusze na działalność kulturalną. Od 1936 r. panie skupiały się w działającym przy zarządzie gminy w Trokach Kole Pań Karaimskich „Katyn Odżahy”, którego celem również była działalność dobroczynna i kulturalno-oświatowa. Honorową jego prezeską została Beata Kobecka (1863-1941), wdowa po prominentnym działaczu karaimskim, Emanuelu ${ }^{11}$. W 1937 r. trockie Koło zorganizowało w domu gminnym świetlicę, gdzie wspólnie z Kołem Młodzieży „Bir-Baw” urządzano odczyty edukacyjne i spotkania towarzyskie. ${ }^{12}$

Można przypuszczać, że inspiracją dla wyjścia poza tradycyjnie pojętą dobroczynność i większego angażowania się trockiej organizacji w działania kulturalno-oświatowe stała się działalność Koła Pań Karaimskich w Haliczu, powstałego rok później niż „Komitet pań” przy Zarządzie Duchownym.

Inicjatorka tego przedsięwzięcia i spiritus movens nie tylko tej organizacji, ale całego życia społeczno-kulturalnego halickiej gminy, Sabina z Samuelowiczów Nowachowiczowa, nauczycielka, była jedną z pierwszych Karaimek, które uzyskały formalne wykształcenie i pracowały zawodowo. Urodziła się 20 stycznia $1885^{13} \mathrm{w}$ Haliczu jako starsze z dwojga dzieci Zachariasza Jakuba Samuelowicza (1857-1888) i Domiceli (Dewory) z Nowachowiczów (1860-1929). Pochodziła z rodziny z tradycjami, a jednocześnie dobrze sytuowanej materialnie, w której dbano o wykształcenie. Kuzyni Sabiny, Izaak (Józef) Nowachowicz (1886-1957) i jej przyszły mąż, Zachariasz Nowachowicz (1883-1960), ukończyli studia prawnicze, a ten ostatni w 1917 r. uzyskał ponadto stopień doktora praw na Uniwersytecie Lwowskim. Inny kuzyn, Leon Eszwowicz (1887-1947) kształcił się w Wyższej Karaimskiej Uczelni Duchowej w Eupatorii na Krymie pod kierunkiem znanego karaimskiego pedagoga, Eliasza Kazasa.

11 S[zymon] F[irkowicz], Troki. Nabożeństwa żałobne, „Myśl Karaimska” 1937-1938, t. 12, z. 12, s. 150.

12 BLAN, sygn. f. 301-250, k. 6; S. F. [Szymon Firkowicz], Troki. Odczyty, „Myśl Karaimska" 1937-1938, t. 12, z. 12, s. 151.

13 W będących w posiadaniu autorki dokumentach osobistych S. Nowachowiczowej (m.in. dokumentach tożsamości, sporządzonym w styczniu 1940 r. wypisie z ksiąg metrykalnych) jako rok urodzenia podano 1885. Jednakże świadectwa szkolne (zawiadomienie o ocenach uzyskanych w klasie II oddziału szkoły dwuklasowej żeńskiej w Haliczu z 1892 r. oraz świadectwo promocji do klasy szóstej z 15 lipca 1895, z podanym rokiem urodzenia 1883) wskazują, że mogła być dwa lata starsza. 
Możliwość kształcenia zapewniono także dziewczętom: Sabinie i jej kuzynce, Annie Nowachowicz, później Ickowiczowej (1883-1942) ${ }^{14}$. Sabina zwana Bunią ${ }^{15}$ naukę rozpoczęła w 1890 r. w szkole dwuklasowej żeńskiej w Haliczu, a następnie tamże w etatowej szkole ludowej 4-klasowej żeńskiej, którą ukończyła w roku 1896. Następnym etapem była szkoła wydziałowa żeńska im. Królowej Jadwigi w Stanisławowie, gdzie uczyła się w trybie eksternistycznym jako tzw. prywatystka.

W 1901 r. wstąpiła do seminarium nauczycielskiego żeńskiego Zofii Strzalkowskiej we Lwowie. Otwarty 1 września 1895 r. jako szkoła średnia sześcioklasowa żeńska, zakład Strzałkowskiej był pierwszą w Galicji szkołą średnią dla dziewcząt z programem gimnazjalnym ${ }^{16}$. Przełożona szkoły dbała o wysoki poziom nauczania, a sama będąc samoukiem, kładła duży nacisk na działalność samokształceniową i rozwijanie zainteresowań uczennic. Nauka w tej placówce bez wątpienia wywarła znaczący wpływ na poglądy i postawę przyszłej prezeski Koła Pań.

W 1904 r. S. Samuelowiczówna uzyskała świadectwo dojrzałości, a tym samym uprawnienia „do tymczasowego pełnienia obowiązków nauczycielki młodszej lub nauczycielki w publicznych szkołach ludowych pospolitych z językiem wykładowym polskim i ruskim, nauczycielki robót ręcznych w szkołach ludowych pospolitych i wydziałowych" i w tym samym roku rozpoczęła pracę w 4-klasowej szkole ludowej pospolitej w Dźwinogrodzie na stanowisku nauczycielki tymczasowej. Dwa lata później uzyskała „Patent na nauczycielkę szkół ludowych pospolitych z językiem wykładowym polskim i ruskim”, obejmujący również „uzdolnienie do uczenia języka niemieckiego jako przedmiotu naukowego". W 1909 r. została przeniesiona do 6-klasowej szkoły ludowej żeńskiej w Bóbrce również na stanowisko nauczycielki tymczasowej. Rok później uzyskała patent na nauczycielkę szkół wydziałowych z prawem do „samodzielnego sprawowania urzędu nauczycielskiego w szkołach wydziałowych z językiem wykładowym polskim, a to do udzielania nauki języka polskiego i niemieckiego, geografii i historyji”. W 1917 otrzymała posadę nauczycielki stałej w Brzozdowcach, lecz nie przyjęła jej i pozostała w Bóbrce jako nauczycielka nadetatowa. 25 listopada 1919 r. wyszła za maż za kuzyna, wspomnianego

14 Zob. Sulimowicz, A., Bryczką do Wodnik. Anna z Nowachowiczów Ickowiczowa (1883-1942), „Awazymyz” 2012, 4 (37), s. 4-8.

15 Pod takim imieniem figuruje na świadectwach szkoły ludowej.

16 Sprawozdanie Dyrekcyi Prywatnego Gimnazjum Żeńskiego Zofii Strzałkowskiej we Lwowie za rok szkolny 1906/07, Lwów 1907, s. 58. 
Zachariasza Nowachowicza, prawnika i w 1921 r. przyjęła posadę nadetatową w 6-klasowej szkole męskiej, a następnie w 7-klasowej publicznej szkole powszechnej w Haliczu (od 1924 r. jako nauczycielka stała), gdzie pracowała do przejścia na emeryturę w 1926 r. Odtąd poświęcała się działalności społecznej, uczestnicząc jako żona adwokata i działacza miejscowej gminy karaimskiej, w życiu tak miasta Halicza, jak i społeczności Karaimów.

Swą społecznikowską pasję realizowała przede wszystkim poprzez działalność Koła Pań Karaimskich. W archiwum $\mathrm{Koła}^{17}$ nie zachował się, niestety, jego statut. Jednakże brudnopisy sprawozdań z działalności za lata 1933-1935 i 1935-1937 oraz inne dokumenty i fotografie pozwalają zarówno prześledzić działalność organizacji, jak i odtworzyć jej program oraz cele.

Koło Pań Karaimskich w Haliczu zostało powołane do życia 19 marca 1932 r. Początkowo skupiało 34 kobiety - wszystkie zamężne Karaimki mieszkające w Haliczu i Załukwi (il. 1), ale w drugim i trzecim roku działalności liczba aktywnych członkiń zmalała do $20^{18}$. Zebrania Koła odbywały się w soboty - w latach 1933-1935 odbyło się ich 80, w latach 1935-1937 - 9019. Lokalu użyczały w swoich domach Estera Abrahamowiczowa, Janina Zarachowiczowa i Salomea Abrahamowiczowa, a od września 1936 r. spotkania odbywały się w świetlicy nowo wybudowanego domu gminnego.

Program zebrań obejmował „czytanie dzienników, wydawnictw karaimskich, referaty, parasza odpowiedniej soboty, lektura polska, omawianie spraw bieżących i potrzeb Koła, a nadto śpiewanie zemer i pieśni karaimskich”20. Parasze były czytane przez duchownych w języku karaimskim „celem zaznajomienia z treścią Biblii i przyswajania czystego języka karaimskiego"21. Ważnym punktem były referaty wygłaszane przez samą prezeskę i zapraszanych gości. Najczęściej byli to ribbi Zarach Zarachowicz, członek zarządu gminy (wygłosił

17 Opuszczając Halicz w 1944 r. i przenosząc się do Krakowa, a następnie Chrzanowa, Sabina Nowachowiczowa zabrała ze sobą teczkę zawierająca dokumenty dotyczące działalności Koła, przede wszystkim teksty referatów. Po śmierci jej i Zachariasza Nowachowicza w 1960 r. archiwum to trafiło w ręce turkologa Józefa Sulimowicza i stanowi obecnie część jego kolekcji.

18 „Sprawozdanie z czynności pracy Koła Pań Karaimskich w Haliczu za czas od 6/5 1933 do 23/3 1935”, nr inw. JSul.VI.08.03. Dalej jako Sprawozdanie 1933-1935.

19 „Walne zebranie «Koła Pań Karaimskich» 20/3 1937. Sprawozdanie organizacyjne z czynności «Koła Pań Karaimskich» w Haliczu za czas od 23/3 1935 do dnia dzisiejszego", nr inw. JSul.VI.08.08. Dalej jako Sprawozdanie 1935-1937.

20 Sprawozdanie 1933-1935.

21 Sprawozdanie 1935-1937. 
12 referatów) i ribbi Leon Eszwowicz, nauczyciel religii (6 referatów). Wśród prelegentów znaleźli się też Nowach Szulimowicz, lekarz, absolwent Wydziału Medycznego Uniwersytetu Jagiellońskiego (1 referat, być może jeszcze jeden), Józef Łobanos, hazzan w Wilnie (2 referaty) oraz Tatar krymski, Ibrahim Otar, stypendysta rządowy z Turcji (1 referat). Prezeska Koła, Sabina Nowachowiczowa wygłosiła w latach 1933-1937 łącznie 6 referatów.

Oprócz zebrań Koło organizowało również wycieczki. W sprawozdaniu za lata 1933-1935 odnotowano dwa wyjazdy na cmentarz w Kukizowie - miały one miejsce zapewne jesienią 1933 i 1934 r. Koło Pań było również organizatorem pierwszej takiej wycieczki, która odbyła się 25 września 1932 r., odnawiając dawną tradycję odwiedzania kukizowskiej nekropolii przez halickich Karaimów przed świętami Rosz ha-Szana i Jom Kippur ${ }^{22}$. Ostatni przed II wojną światową wyjazd do Kukizowa Koło zorganizowało we wrześniu 1938 r. ${ }^{23}$. W lipcu 1933 r. część członkiń z prezeską na czele wybrała się z wizytą do bratnich gmin. Dnia 5 lipca grupa 15 osób zawitała do Łucka, a następnego dnia, po zwiedzeniu kienesy i miasta, udała się do Trok i Wilna ${ }^{24}$. W Trokach zwiedzano kienesę i archiwum przy Zarządzie Duchownym ${ }^{25}$. Członkinie Koła spotkały się również z małżonką hachana, Wierą Szapszałową, co uwieczniono na wspólnej fotografii (il. 2).

W sierpniu 1933 r. Koło Pań podejmowało w Haliczu ułlu hazzana S. Firkowicza. Pobyt duchownego urozmaicono wypadem w Karpaty do Jaremcza (il. 3). W trakcie tej wizyty, jak Nowachowiczowa odnotowała w sprawozdaniu, „podjęto za jego [tj. Firkowicza] inicjatywą żywszą akcję budowy domu gminnego, tak bardzo potrzebnego dla koncentracji życia karaimskiego” ${ }^{26}$. W „Księdze Pamiątkowej” Koła ${ }^{27}$ znajdują się wpisy złożone przez innych gości: delegatów Związku Strzeleckiego, prof. Tadeusza Kowalskiego z żoną (po karaimsku!), Heleny Łobanosowej, żony hazzana wileńskiego Józefa, z córkami, członków ekspedycji włoskiego antropologa prof. Corrado Giniego, tureckich stypendystów, Tatarów krymskich Ibrahima Otara (będzie o nim mowa dalej) i Selima Ortaya, lektora języka arabskiego w Instytucie Orientalistycznym Uniwersytetu

22 [Szulimowicz, Szymon (właściwie Samuel), Mardkowicz Aleksander], Zeretterinde Kukizownun, „Karaj Awazy” 1932, z. 3 (5), s. 11. Zob. też: Na kukizowskim cmentarzu, przeł. Anna Sulimowicz, „Awazymyz” 2009, z. 2 (23), s. 3-6.

23 J[ózef] S[ulimowicz], Pielgrzymka na cmentarz karaimski w Kukizowie, „Myśl Karaimska" 1937-1938, t. 12, z. 12, s. 149;

24 Wycieczka z Halicza, „Myśl Karaimska” 1932-1934, t. 10, z. 10, s. 121;

25 Wycieczka Karaimów z Halicza i Łucka, tamże, s. 117.

26 Sprawozdanie 1933-1935.

27 Założona 27 października 1933 r. Nr inw. J.Sul.I.57. 
Warszawskiego Ahmeda Kherbiego i wreszcie Aleksandra Mardkowicza, pisarza i wydawcy z Łucka.

Tego ostatniego Koło Pań wspólnie z Kołem Młodych Karaimów podejmowało w Haliczu w maju 1937 r. ${ }^{28}$. Wcześniej, 21 marca tegoż roku KMK urządziło akademię ku czci poety i wydawcy, podczas której nadano mu tytuł Członka Honorowego gminy w Haliczu, a stosowny dyplom przedstawiciele młodzieży wręczyli Mardkowiczowi 1 maja w Łucku²9. Witając gościa w progach nowo otwartego domu gminnego, Nowachowiczowa stwierdziła w swoim przemówieniu: „[...] kobieta karaimska, jakkolwiek zasięgiem swych czynności nie wykracza daleko poza próg swego ogniska domowego, jednak zdaje sobie sprawę, że na barkach jej spoczywa wielka odpowiedzialność wychowania narodowego przez zaszczepianie w młodych duszach miłości do wszystkiego, co jest karaimskie. [...] Wielce szanowny gość nasz, autor i wydawca jedynego pisma karaimskiego „Karaj Awazy” nie wyobraża sobie może, jak bardzo ułatwia nam tę pracę wychowawczą artykułami swemi, z których bije ożywcze źródło miłości języka ojczystego" ${ }^{30}$.

Pamięć osób zasłużonych dla społeczności karaimskiej czczono uroczystymi akademiami. 14 lutego 1934 r. zorganizowano taką dla uczczenia pamięci Eliahu Kazasa (1832-1912), wybitnego karaimskiego pedagoga i założyciela Wyższej Karaimskiej Uczelni Duchownej w Eupatorii, którego uczniem był halicki mełamed, ribbi Lewi (Leon) Eszwowicz. Po nabożeństwie celebrowanym wspólnie przez ribbi Zaracha Zarachowicza, ribbi Mordechaja Leonowicza (hazzana) i ribbi Lewiego ${ }^{31}$, podczas którego ten ostatni odczytał ułożoną przez siebie ku czci

28 Przemówienie powitalne pisane ręką S. Nowachowiczowej (nr inw. JSul.VI.08.18.02) nosi datę 16 maja, zaś wpis Mardkowicza w „Księdze pamiątkowej” 17 maja 1937 r. W notatce w „Myśli Karaimskiej” podano natomiast, że powitanie działacza miało miejsce 5 maja. Być może to błąd drukarski i powinno być 15 maja. Zob. J. S. [Józef Sulimowicz], Aleksander Mardkowicz członkiem honorowym gminy karaimskiej w Haliczu, „Myśl Karaimska” 1937-1938, t. 12, z. 12, s. 148.

29 J[ózef] S[ulimowicz], Aleksander Mardkowicz... s. 148.

30 JSul.VI.08.18.02.

31 Dzymatynda Halicnin, „Karaj Awazy” 1934, z. 7, s. 25. Maszynopis notatki stanowiącej podstawę tego artykułu, sporządzony prawdopodobnie przez Zaracha Zarachowicza, znajduje się w archiwum Koła, nr inw. JSul.VI.08.13.06. 
zmarłego elegię żałobną kyna, ${ }^{32}$ prezeska Koła wygłosiła referat o życiu i dokonaniach zmarlego ${ }^{33}$, przygotowany na podstawie broszury B. Eliaszewicza ${ }^{34}$.

Z okazji 250-lecia przybycia do Halicza Josefa ben Szemuela Hamaszbira 24 listopada 1935 r. Koło również zorganizowało akademię. Jej dokładny przebieg nie jest znany, na łamach prasy karaimskiej nie opublikowano bowiem żadnej relacji ${ }^{35}$. W archiwum Koła zachowały się teksty przemówienia wygłoszonego z tej okazji przez hazzana M. Leonowicza ${ }^{36}$ oraz referatu Nowachowiczowej, jak też maszynopis anonimowego tekstu (być może powstałego z zamiarem publikacji w „Myśli Karaimskiej”?) o znalezionych w Haliczu dwóch rękopisach, z których jeden okazał się autografem Hamaszbira zawierającym postanowienia umowy z przedstawicielami halickiej społeczności o zachowaniu nakazów religijnych i zawierający datę przybycia uczonego męża - rok 1685/1686. Referat Nowachowiczowej pozwala ustalić, że autorem wspomnianego tekstu w maszynopisie był Z. Zarachowicz, który przejął manuskrypty od Samuela Mordkowicza (1848-1930), który z kolei ocalił je przed spaleniem w piecu. Nowachowiczowa powtarza podane przez Zarachowicza informacje, uzupełniając je o interesujący szczegół pochodzący z ustnych przekazów dotyczących epoki sprzed przyjazdu Hamaszbira: „według smutnego podania z tych czasów nie było wcale mitpallela [zapisano alfabetem hebrajskim - uwaga ASul], który by mógł odprawiać nabożeństwo, tak że rzekomo jedna ze współczesnych kobiet pełniła te obowiązki”. Inną, choć podobnego rodzaju opowieść zasłyszał od swojego stryja, Izaaka Abrahamowicza, hazzana w latach 1922-1924 i 1926-1933, Zygmunt Abrahamowicz ${ }^{37}$.

Kolejną z form działalności Koła była praca z dziećmi (il. 4). Przedstawiciele najmłodszego pokolenia Karaimów wzięli udział we wspomnianej akademii ku

32 JSul.VI.08.13.03.

33 JSul.VI.08.13.01.

34 El'jaševič, Boris Saad'evič, I. I. Kazas. Ego žizn', naučno-literaturnaja, pedagogičeskaja i obščstvennaja dejatel'nost'. Biografičeskij očerk, wydana w Eupatorii w $1918 \mathrm{r}$. W archiwum Koła Pań znajduje się dokonane przez Sabinę Nowachowiczową tłumaczenie tej broszury w formie oprawionego maszynopisu, nr inw. JSul.VI.08.12.

35 Wzmianka o akademii, bez podanej daty wydarzenia, znajduje się jedynie w notatce Z. Zarachowicza, Koło Pań Karaimskich, „Myśl Karaimska”, 1935-1936, t. 11, z. 11, s. 119.

36 "Chyzlamak kinde jilynyn 250. kelivinin ha rav-ribbi Josef ha-Mašbirnin Deraznadan Halicke", nr inw. JSul.VI.08.42.

37 Z. Abrahamowicz, Dzieje Karaimów w Haliczu, „Przegląd Orientalistyczny” 2001, z. 1-2 (196-197), s. 12-13. 
czci Eliasza Kazasa, recytując utwory zmarłego w języku hebrajskim. ${ }^{38}$ Urządzano także okolicznościowe przedstawienia dziecięce "grane w języku polskim i karaimskim" ${ }^{39}$. Można przypuszczać, że wykorzystywano przy tym wiersze i utwory sceniczne autorstwa ułlu hazzana S. Firkowicza, podobnie jak miało to miejsce w wypadku spektakli karaimskiego teatru amatorskiego ${ }^{40}$. Być może korzystano także z utworów dla dzieci pióra Al. Mardkowicza publikowanych na łamach „Karaj Awazy”. W okresie od maja 1935 do marca 1937 takich przedstawień zorganizowano sześć, wystawiane były również w latach 1935-1937 i jak wynika z zachowanych zdjęć, również w roku 1938 (il. 5 i 6). Przedstawienia dziecięcego teatrzyku tradycyjnie stanowiły także element obchodów święta Purim, podczas których Koło Pań wręczało najmłodszym upominki kupione za kwotę 50 zł, przekazywaną corocznie na ten cel przez hachana Hadży Seraję Szapszała.

Dochód ze sprzedaży biletów na przedstawienia przeznaczano na cele dobroczynne, głównie zakup wyposażenia do kienesy i domu gminnego. I tak w latach 1935-1937 z funduszy tych oraz ze składek członkiń Koła „odnowiono kienesę górną, przyozdobiono dywanami i przykryciami filarów. Do kienesy głównej sprawiono «kaporet $»^{41}-$ «parochet $»^{42}$ na ołtarz, przykrycia na dochan ${ }^{43}$ i stoliki boczne, Tora-uprak ${ }^{44}$, lampki oliwne, araba kanfot ${ }^{45}$ dla wspólnego użytku członków gminy i mały dla użytku dziatwy" ${ }^{46}$ (il. 7). W latach 1935-1937 zebrano kwotę 245 zł, którą przeznaczono na wykończenie domu gminnego. Zakupiono również dywan przed ołtarz w kienesie, a hachanowi H. S. Szapszałowi ofiarowano „W dowód czci i hołdu” herb karaimski wykonany haftem, w ramie, z dedykacją.

Najbardziej charakterystycznym przejawem działalności halickiego Koła Pań były wygłaszane na sobotnich spotkaniach referaty. Na podstawie sprawozdań i zachowanych tekstów wystąpień można określić ich liczbę na ponad $30 \mathrm{w}$ ciągu siedmiu lat istnienia Koła. Zebrania, na których były prezentowane (w języku

38 Dzymatynda Halicnin, „Karaj Awazy” 1934, z. 7, s. 25.

39 Tamże.

40 Jak świadczą zachowane teksty (nr inw. JSul.I.56.01-04), wystawiono sztuki S. Firkowicza „Chatan”, „Neni kłedłer”, „Kipcehinde tirliknin” i „Janhyłdy”. Reżyserem przedstawień był Leon Sulimowicz.

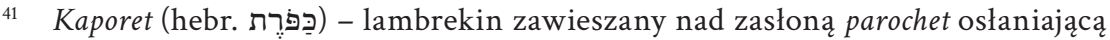
drzwiczki ołtarza, za którymi umieszczono zwoje Tory.

42 Parochet (hebr. פָּרָת) - zasłona ołtarza.

43 Dochan (karaim.) - pulpit w formie stołu do wykładania i czytania zwojów Tory.

44 Tora-uprak, wł. Tora uprahy (kar.) - dosł. strój Tory, pokrowiec na zwoje.

45 Araba kanfot (karaim.), właśc. arba kenafot, z hebr. אַרְבַּע כְנָּפוֹת - szal modlitewny.

46 Sprawozdanie 1933-1935. 
karaimskim i polskim) były otwarte. Słuchaczami były nie tylko członkinie Koła, lecz także młodzież skupiona w Kole Młodych Karaimów i członkowie gminy. Tematyka wystąpień była dość zróżnicowana, można jednak wyróżnić cztery główne zakresy tematyczne:

- Pismo Święte Starego Testamentu i zasady religii karaimskiej,

- dzieje karaimizmu i Karaimów oraz literatura karaimska,

- zagadnienia psychologiczno-wychowawcze,

- wiedza ogólna.

Do pierwszej grupy zaliczyć można referaty wygłoszone w języku polskim i karaimskim przez Z. Zarachowicza: „Postacie kobiece w Biblii” "47, „Zagadnienia dogmatyczne religii karaimskiej i dziesięć zasad wiary”48, „Treny Jeremiasza i wstęp historyczny" ${ }^{49}$ oraz wystąpienia o potrzebie modlitwy ${ }^{50}$ oraz zasadach koszerności i uboju ${ }^{51}$, jak też prezentowane wyłącznie w języku karaimskim wystąpienia L. Eszwowicza poświęcone Mojżeszowi jako ustawodawcy narodu Izraela $^{52}$, Judycie ${ }^{53}$, Nabuchodonozorowi ${ }^{54}$ oraz odpowiedziom Daniela udzielonym Cyrusowi ${ }^{55}$. Do grupy tej należą również wystąpienia J. Łobanosa: „Kobieta

47 Wygłoszony 10 marca 1934 r., prezentował postaci Sary, Rebeki, Racheli i Lei, Jochewed, Mariam, Rachaw (Rachab), Debory, córki Jiftacha (Jeftego), żony Manoacha, Chany matki Samuela, Abigail żony Nabala oraz Rut. Rękopis nr inw. JSul.VI.08.19.

48 Referat odnotowany w Sprawozdaniu 1933-1935.

49 Wygłoszony w j. karaimskim. Rękopis nr. inw. JSul.VI.08.32. W kolofonie data 2 tammuza 5696 (22 czerwca 1936 r.).

50 Rękopis nr. inw. JSul.VI.08.40. Tytuł w j. hebrajskim: בשם אשר לו נאוה שבת ותהלה אכתוב כמה דברים בענין תפלה.

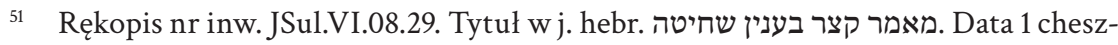
wan 5698 (6 października 1937 r.).

52 Rękopis nr. inw. JSul.VI.08.37.

53 W Sprawozdaniu 1933-1935 określono temat jako „Judyta opr. według apokryfów”. Tytuł oryginalny „Kotarmahy bahatyr katyn icin Jehudit icin”, nr. inw. JSul.VI.08.45.

54 Rękopis nr. inw. JSul.VI.08.38. Tytuł w języku polskim: „Fragmenty z życia Nabuchodonozora króla babilońskiego” i karaimskim: „Tirliklerinden Nevukadnecarnyn malaknyn Babilnin”.

55 Nr. inw. JSul.VI.08.34. Tytuł kar. „Sormaklary Korešnin bijnin Parasnyn Danielden ol naviden dinlik nerselercin”. Referat figuruje w sprawozdaniu 1935-1937 pod tytułem „O rzeczach wiary prorok Daniel Cyrusowi perskiemu”. Rękopis został, prawdopodobnie przez S. Nowachowiczową, opatrzony datą $15 / 5$ bez podania roku. W sobotę dzień ten wypadał w roku 1937, co wykracza poza okres sprawozdawczy. Być może jest to data otrzymania tekstu referatu, a nie jego wygłoszenia. 
w Biblii” w języku polskim ${ }^{56}$ i „Ogólne zasady wiary karaimskiej” w języku karaimskim. ${ }^{57} \mathrm{~W}$ archiwum Koła znajdują się jeszcze dwa inne niepodpisane rękopiśmienne teksty w języku karaimskim tematycznie przynależące do tej grupy jako poświęcone dziejom Izraela do zburzenia pierwszej świątyn ${ }^{58}$ oraz świętości soboty ${ }^{59}$. Charakter pisma wskazuje, że ich autorem był Z. Zarachowicz.

Druga grupę tworzą referaty Z. Zarachowicza: „Historia Kościoła karaimskiego” i „Działalność Eliasza Kazasa na polu pracy społecznej dla narodu karaimskiego", o których jednak brak bliższych danych ${ }^{60}$, wystąpienie w języku karaimskim poświęcone przyczynom rozłamu Izraela na Karaimów i Rabbanitów ${ }^{61}$, wystąpienie L. Eszwowicza w języku karaimskim pod tytułem „Charakterystyka wysokiego urzędnika karaima Binjamina Aga przy chańskim dworze”62, nie odnotowane w sprawozdaniach, więc prawdopodobnie wygłoszone po 20 marca 1937 r. O referacie S. Nowachowiczowej „Kazas, jego życie i dzieła” była już mowa wyżej. Kwestią otwartą pozostaje, czy dokonany przez N. Szulimowicza przekład z hebrajskiego na polski artykułu „Książę Anan założyciel religii karaimskiej jako nawoływacz do łączenia się narodów za pośrednictwem zjednoczenia wyznań” autorstwa Towiji Lewi Babowicza, który to przekład zachował się w archiwum Koła ${ }^{63}$, był lub miał być podstawą referatu czy też może został odczytany na którymś ze spotkań w roku 1935 lub później.

56 Nr. inw. JSul.VI.08.20. Maszynopis opatrzono datą 18/07 1936.

57 Rękopis nr. inw. JSul.VI.08.31.

58 Rękopis nr inw. JSul.VI.08.33. Tytuł w j. hebr. עד חרבן z דברי ימי ישראל dopisanym ołówkiem, brak daty.

59 Rękopis nr inw. JSul.VI.08.41. Tytuł w j. hebr. על קדושת השבת. Dopisana data: 4/9 1937.

60 Teksty nie zachowały się, wymieniono jedynie tematy w Sprawozdaniu 1933-1935.

${ }_{61}$ Wymieniony w Sprawozdaniu 1935-1937. W archiwum Koła znajdują się dwa rękopisy w formie książeczek (nr. inw. JSul.VI.08.28a i JSul.VI.08.28b) zawierające tekst w j. hebrajskim zatytułowany חלוקת הקראים והרבנים (fol. 2ró), stanowiący zapewne podstawę tego referatu. Pierwotnie miał prawdopodobnie zostać sporządzony w języku karaimskim, o czym świadczy urwany początek, zob. JSul.VI.08.28a fol. 1 ro.

62 Rękopis JSul.VI.08.43. Oprócz tytułu w j. polskim także w j. karaimskim: „Tudzurmahy tirliklerinin bir israelnin ol indelgen Binjamin Aga”. W kolofonie (fol. $1 \mathrm{v}^{\mathrm{o}}$ ) imię i nazwisko autora i informacja o odczytaniu referatu w Kole Pań.

63 Maszynopis, nr inw. JSul.VI.08.19. Dedykacja od N. Szulimowicza dla S. Nowachowiczowej datowana 1 stycznia 1934 r. (s. 1). W kolofonie (s. 10) informacja T. Lewi Babowicza o ukończeniu pisania artykułu w Sewastopolu 1 sierpnia 1917 r. i przetłumaczeniu go przezeń na j. hebrajski 14 kwietnia 1933 w Symferopolu. Przekład na j. polski N. Szulimowicza 18 czerwca 1933 r. w Krakowie. Na s. 10-11 tłumaczenie 
Osobną podgrupę stanowią wystąpienia omawiające ważne dzieła karaimskich uczonych. Ponieważ z nielicznymi wyjątkami kobiet „świętego języka” nie nauczano, celem tego rodzaju prelekcji było „pogłębić znajomość utworów tak religijnych, jak i literackich niedostępnych z powodu nieznajomości języka biblijnego"64. I tak Zecher caddikim Mordechaja Sułtańskiego przedstawił Z. Zarachowicz ${ }^{65} \mathrm{w}$ języku polskim, a Adderet Elijahu Basziacziego - L. Eszwowicz ${ }^{66} \mathrm{w}$ języku karaimskim. Do tej grupy należy włączyć również referaty N. Szulimowicza pt. „Stosunek nauki chrześcijańskiej do karaimizmu i jego prace literackie” ${ }^{67}$, którego tematem są zainteresowania XVII-wiecznych europejskich biblistów Karaimami i wydania dzieł karaimskich uczonych, oraz przygotowany przez Z. Zarachowicza „Ze wspomnień Samuela Pigita hazzana Jekat[erynosławskiego]" ${ }^{68}$, prezentujący obszerne fragmenty wstępu do dzieła Pigita pt. Igeret Nidhe Šemu'el, wydanego w Petersburgu w 1894 r.

Autorką referatów dotyczących kwestii psychologiczno-wychowawczych była prezeska Koła, S. Nowachowiczowa. W wymienionym w sprawozdaniu za lata 1933-1935 referacie pt. „Rozwój psychiczny dziecka na podstawie Dr. Kreutza”69 omawiała pracę Mieczysława Kreutza ${ }^{70}$, zaś tezy zawarte w publikacji Charakter i typy jedynaków Franciszka Śnihoty ${ }^{71}$ przedstawiła w tekście bez tytułu ${ }^{72}$. Własne przemyślenia (wraz z zarysem historycznym dążeń do równouprawnienia kobiet) zaprezentowała z kolei w referacie pt. „Kilka myśli o psychice kobiety współczesnej w Polsce oraz pogląd na życie i rozwój psychiczny kobiety karaimskiej”73 z 1934 r.

listu T. Lewi Babowicza z 3 maja 1933 r. do N. Szulimowicza, w którym Babowicz m.in. opisuje okoliczności powstania artykułu, jak też odpowiada na prośbę N. Szulimowicza o napisanie krytycznej recenzji publikacji R. Fahna: „pospieszyłem spełnić jego prośbę, aby uratować z rąk tego pisarza nasz honor, który on poniża, jednak do tej pory nie posłałem krytyki na zewnątrz dla spokoju, jak doradziły mi moje myśli i niektórzy z synów naszego narodu" (s. 11).

64 Sprawozdanie 1935-1937.

65 Rękopis JSul.VI.08.10.

66 „Birnece sezler seferden ol indelhen «Adderet Elijahu»”, nr inw. JSul.VI.08.44.

${ }_{67}$ Rękopis JSul.VI.08.21.

68 Rękopis JSul.VI.08.11.

${ }^{69}$ Rękopis JSul.VI.08.22.

70 M. Kreutz, Rozwój psychiczny młodzieży, Książnica Atlas, Warszawa-Lwów 1931.

71 F. Śnihota, Charakter i typy jedynaków, Biblioteka Kwartalnika Pedagogicznego 3, nakładem Stowarzyszenia Chrześcijańsko-Narodowego Nauczycielstwa Szkół Powszechnych, Warszawa 1931.

72 Rękopis JSul.VI.08.06.

73 Rękopis JSul.VI.08.27, datowany 13 maja 1934 r. 
Warto w tym miejscu zaznaczyć, że tekst ten zawiera również informacje na temat historii ruchu kobiecego i ówczesnej sytuacji w zakresie równouprawnienia. Omówienie pozycji kobiet w różnych kulturach od czasów prehistorycznych po współczesność i zarys rozwoju ruchów emancypacyjnych zawiera maszynopis o nr inw. JSul.VI.08.09, zachowany w Archiwum Koła, nie opatrzony jednak ani nazwiskiem autora, ani datą, ani też pieczęcią Koła, co nie pozwala jednoznacznie stwierdzić, czy jego autorką jest Nowachowiczowa i czy mamy do czynienia z tekstem referatu czy też wypisem z jakiejś publikacji. Jednym z ostatnich referatów wygłoszonych przez Nowachowiczową podczas spotkań Koła był zapewne ten pod tytułem „Rola matki karaimki w społeczeństwie”, w podtytule zawierający informację, że został wygłoszony w dniu uroczystości „Dzień matki” ${ }^{\text {”4 }}$.

Ostatnią grupę stanowią referaty prezentujące wiedzę ogólną, nie związaną lub związaną pośrednio z religią i pochodzeniem Karaimów. Według sprawozdania za lata 1933-1935 S. Nowachowiczowa wygłosiła dwa referaty tego rodzaju, zatytułowane „Mieszkańcy Palestyny pierwotnej 1400 lat przed Chrystusem” oraz „Palestyna na tle geografii ogólnej”, przygotowane zapewne w oparciu o jakieś źródła książkowe. Ich teksty nie zachowały się w archiwum Koła, znaleźć tam można za to inny, poświęcony wykopaliskom w Egipcie ${ }^{75}$. Rękopis jest niesygnowany, jednakże charakter pisma wskazuje na S. Nowachowiczową jako jego autorkę.

Za zorganizowaniem w styczniu 1936 r. wystąpienia Ibrahima Otara (19131986), studiującego w Polsce Tatara krymskiego, który na zebraniu Koła Pań przedstawił kwestię niepodległości Krymu, stał zapewne Józef Sulimowicz (1913-1973), członek Koła Młodych Karaimów i student turkologii w nowo otwartym Instytucie Orientalistycznym Uniwersytetu Warszawskiego. Utrzymywał on bliskie kontakty z przebywającymi w Polsce Tatarami: ze wspomnianym tu Ibrahimem, a także z Abdullahem Zihni Soysalem (1905-1983), oraz bratem Ibrahima, Ismailem Otarem (1911-2005), późniejszym redaktorem czasopisma „Emel” i współzałożycielem Fundacji Badania i Popularyzowania Kultury Tatarów Krymskich (Kırım Türk Kültürünü Araştırma ve Tanıma Vakfı). Przed wystąpieniem w Kole Pań Otar wygłosił referat dla młodzieży. Niestety, teksty tych bez wątpienia interesujących referatów nie zachowały się. Informacji o ich treści dostarcza jednak notatka zamieszczona w kwartalniku „Wschód-Orient” prawdopodobnie przez Sulimowicza: „Prelegent, po zobrazowaniu dziejów Krymu i walk wyzwoleńczych podkreślił konieczność podniesienia braterskich stosunków między Karaimami

74 Rękopis JSul.VI.08.02. Opatrzony jest jednak datą 5 sierpnia 1939 r., podczas gdy Dzień Matki obchodzono na ogół w maju.

75 Maszynopis nr inw. JSul.VI.08.23, datowany 25 września 1937 r. 
i Tatarami, - jako narodów o wspólnej kulturze, języku i wspólnej ojczyźnie, wyrażając głęboką wiarę, iż tylko w zgodzie i jedności narody turko-tatarskie zdołają się wyzwolić z jarzma moskiewskiego. (...) Drugi odczyt p. Otar wygłosił w Kole Pań Karaimskich (...) kładąc główny nacisk na kwestię kobiecą i rolę kobiet krymskich w ruchu niepodległościowym na Krymie i obecnie na emigracji”"

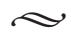

Z powyższego opisu działań Koła wyłania się pozytywistyczny obraz i samej Nowachowiczowej, i kreowanego przez nią ideału kobiety karaimskiej: strażniczki tradycji, obyczaju i języka, posiadającej w tym zakresie niezbędną wiedzę, by przekazywać ją swoim dzieciom/następnym pokoleniom. „Dzisiejsza kobieta karaimska [...] jest skarbniczką naszych tradycji i wychowawczynią w tej tradycji swej rodziny dla utrzymania przyszłości naszego narodu. ${ }^{\prime 77}$ - pisała prezeska Koła. Kładąc nacisk na samokształcenie, podkreślała rolę kobiety w ugruntowywaniu i zachowywaniu poczucia tożsamości tak wyznaniowej, jak i narodowej jako czynnika mającego przeciwdziałać niebezpieczeństwu asymilacji: „(...) uświadomiona społecznie stojąc na straży domowego ogniska, pomaga mężowi zajętemu pracą zawodową w wychowaniu dzieci, utrwalając w nich ducha religijnego i znajomość języka karaimskiego, by młodzież wyszedłszy za obręb swojej gminy miała te pierwiastki tak wrośnięte w serce i duszę, że żadna zawierucha życiowa nie zdoła je złamać. Dzisiaj zadanie to jest tem trudniejsze i większa odpowiedzialność spada na kobietę karaimską, że kiedy dawniej nastawienie naszego narodu było wyłącznie religijne i młodzież rzadko kiedy opuszczała rodzinne swoje progi, dzisiaj potrzeby życia są większe - musimy iść z kulturą i cywilizacją doby obecnej, a przez to samo być poddani wpływom zewnętrznym. (...) musi sama nad sobą pracować, by podołać zadaniu (...), gdyż cały ciężar wychowania spoczywa na jej barkach, (...) która zaś z nich nie wejdzie w ramy tej pracy nad dobrem naszej społeczności, będzie odpowiadać sumieniem przed Bogiem i społeczeństwem"78.

Działania Nowachowiczowej i prowadzonego przez nią Koła charakteryzują się równorzędnym traktowaniem trzech elementów: religii i tradycji, języka i tożsamości narodowej oraz wiedzy ogólnej. Można w tym dostrzec kontynuację w pewnym sensie idei I. I. Kazasa na gruncie gminy halickiej. Niewątpliwie

\footnotetext{
76 Z życia Karaimów, „Wschód-Orient” 1935-1936, rok VII, nr 4 (1935) - 1 (1936), s. 96.

77 Sprawozdanie 1933-1935.

78 Sprawozdanie 1935-1937.
} 
działania Koła i jego prezeski wpisują się w nurt przemian zainicjowany przez Hadży Seraję Szapszała, który w 1927 r. objął urząd hachana. Kwestią otwartą pozostaje rola małżonki hachana, Wiery Szapszałowej z domu Egiz jako inspiratorki edukacyjnej działalności karaimskich organizacji kobiecych w Polsce. Wydaje się, że w wypadku Nowachowiczowej idea utworzenia Koła była odbiciem jej własnych zapatrywań i zainteresowań, a wsparcie ze strony wyższego karaimskiego duchowieństwa (hachana Szapszała i ułlu hazzana S. Firkowicza), czy fakt angażowania się żony hachana w działalność społeczną wśród kobiet stanowiły dodatkowe czynniki sprzyjające.

Warto w tym miejscu zwrócić uwagę na sam modus operandi Koła. Mimo postulatu samokształcenia edukacyjna część jego działalności charakteryzuje się intensywnym udziałem przewodniczącej i zapraszanych prelegentów (wyłącznie mężczyzn) przy praktycznie zerowej aktywności członkiń. W materiałach archiwalnych nie znalazłam jakichkolwiek śladów działań edukacyjnych prowadzonych przez skupione w Kole panie, nawet przez przedstawicielki młodszego pokolenia, ani też prób angażowania ich w ten rodzaj aktywności. Oczywiście, nie oznacza to, że ich uczestnictwo w Kole było całkowicie bierne. Zapewne w innych działaniach, przy organizacji imprez, w pracach na rzecz domu modlitwy wykazywały więcej inicjatywy. W zakresie edukacji pozostawały jednak, jak się wydaje, wyłącznie biernymi słuchaczkami.

Choć kilka referatów wygłoszonych na spotkaniach Koła dotyczyło roli i pozycji kobiet, a w jednym poruszono nawet kwestie praw kobiet i rozwoju ruchu feministycznego, próżno szukać tam wezwań do równouprawnienia, postulatów równego dostępu do nauki, pracy zawodowej czy prawa głosu dla Karaimek. Jeśli nawet tego rodzaju kwestie były poruszane na spotkaniach, nie pozostał po tym żaden pisany ślad. Obraz kobiety, jaki kreśli Nowachowiczowa w Sprawozdaniach, jest zdecydowanie tradycyjny: niepracująca zawodowo (praca zarobkowa to domena męża - patrz cytat wyżej), poświęcająca się domowi i dzieciom, które wychowuje w karaimskim duchu, przekazując im podstawy wiary, świadomość pochodzenia i język. Przypomina to pod pewnymi względami postawę polskich feministek po I wojnie światowej, gdy walka o równouprawnienie zeszła na dalszy plan, a pierwszorzędnym celem stała się powojenna odbudowa ${ }^{79}$. Takie podejście można dostrzec w całokształcie poczynań Koła, choć w jego działalności nie zaznaczają się typowe dla okresu międzywojennego kwestie zaprzątające uwagę działaczek polskiego

79 Ruch kobiecy w słuzbie społeczeństwu. Rozmowa Weroniki Grzebalskiej z Katarzyną Sierakowską. http://nowe-peryferie.pl/index.php/2013/07/ruch-kobiecy/ (20.09.2015). 
ruchu kobiecego, jak świadome macierzyństwo, aktywność zawodowa kobiet, działania na rzecz pokoju. W tak niewielkim środowisku, jakim była społeczność karaimska w Haliczu licząca w dwudziestoleciu międzywojennym około 130-140 osób, trudno mówić o jakimś ruchu kobiecym, lecz sam fakt działania Koła można uznać za oznakę zmiany tak pozycji kobiet, jak i postaw reprezentowanych przez nie same.

\section{Bibliografia}

Abrahamowicz, Zygmunt, Dzieje Karaimów w Haliczu, „Przegląd Orientalistyczny” 2001, z. 1-2 (196-197), s. 3-16.

Dzymatynda Halicnin, „Karaj Awazy” 1934, z. 7, s. 25.

El'jaševič, Boris Saad'evič, I. I. Kazas. Ego žizn', naučno-literaturnaja, pedagogičeskaja i obščestvennaja dejatel'nost'. Biografičeskij očerk, Eupatoria 1918.

Gąsiorowski, Stefan, Karaimi $w$ Koronie i na Litwie w XV-XVIII wieku, Kraków-Budapeszt 2008.

Karaucu, Unutkan ribbimiz, „Karaj Awazy” 1932, z. 1(3), s. 18-22. Tłumaczenie na język polski: Zapomniany nauczyciel, przeł. A. Sulimowicz, „Awazymyz” 2006, z. 2 (13), s. 13-18.

K[obecki], E[mil], Z Wileńskiego Stowarzyszenia Karaimów, „Myśl Karaimska” 1924, t. 1, z. 1, s. 24-25.

$\mathrm{K}$ [obecki], E[mil], Z konferencji przedstawicieli organizacyj karaimskich (dnia 30 listopada 1924 r.), „Myśl Karaimska” 1925, t. 1, z. 2, s. 33-36.

Kreutz, Mieczysław, Rozwój psychiczny młodzieży, Książnica Atlas, Warszawa-Lwów 1931.

Ruch kobiecy w stużbie społeczeństwu. Rozmowa Weroniki Grzebalskiej z Katarzyną Sierakowską. http://nowe-peryferie.pl/index.php/2013/07/ruch-kobiecy/ (20.09.2015).

Sprawozdanie Dyrekcyi Prywatnego Gimnazjum Żeńskiego Zofii Strzałkowskiej we Lwowie za rok szkolny 1906/07, Lwów 1907.

Sulimowicz, Anna, Bryczką do Wodnik. Anna z Nowachowiczów Ickowiczowa (1883-1942), „Awazymyz” 2012, z. 4 (37), s. 4-8.

S[ulimowicz], J[ózef], Aleksander Mardkowicz członkiem honorowym gminy karaimskiej w Haliczu, „Myśl Karaimska” 1937-1938, t. 12, z. 12, s. 148.

S[ulimowicz], J[ózef], Pielgrzymka na cmentarz karaimski w Kukizowie, „Myśl Karaimska” 1937-1938, t. 12, z. 12, s. 149.

[Szulimowicz, Szymon (właściwie Samuel), Mardkowicz Aleksander], Zeretłerinde Kukizownun, „Karaj Awazy” 1932, z. 3 (5), s. 11-16. Tłumaczenie na język polski: Na kukizowskim cmentarzu, przeł. Anna Sulimowicz, „Awazymyz” 2009, z. 2 (23), s. 3-6.

Śnihota, Franciszek, Charakter i typy jedynaków, Biblioteka Kwartalnika Pedagogicznego 3, nakładem Stowarzyszenia Chrześcijańsko-Narodowego Nauczycielstwa Szkół Powszechnych, Warszawa 1931.

Wycieczka z Halicza, „Myśl Karaimska” 1932-1934, t. 10, z. 10, s. 121. 
Wycieczka Karaimów z Halicza i Łucka, „Myśl Karaimska” 1932-1934, t. 10, z. 10, s. 117. Zarachowicz, Zarach, Koło Pań Karaimskich, „Myśl Karaimska” 1935-1936, t. 11, z. 11, s. 119. $Z$ walnego zgromadzenia $w$ Trokach $w$ dniu 18 stycznia 1925 r., „Myśl Karaimska” 1925, t. 1, z. 2, s. 39-40.

\section{Ilustracje}

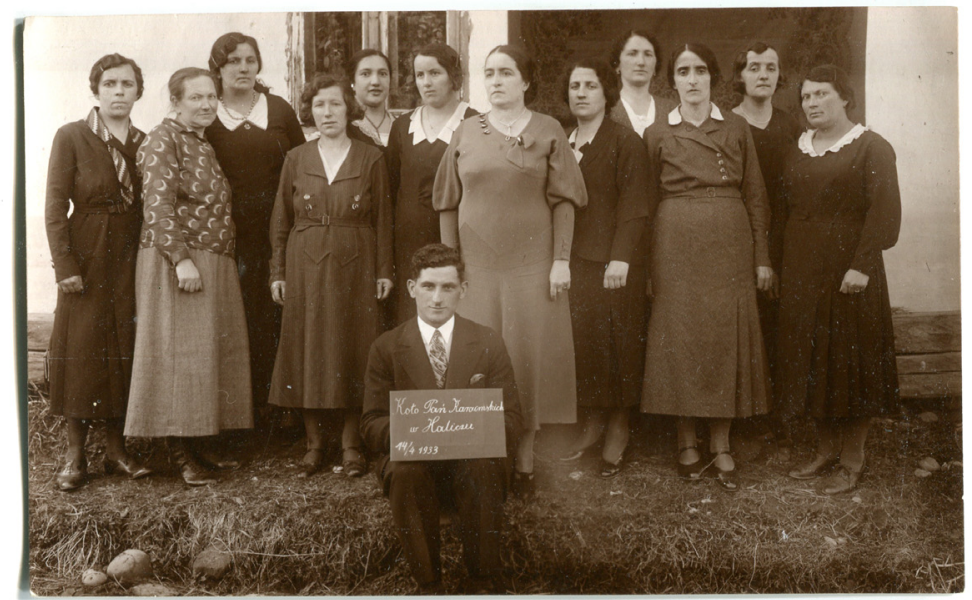

Ilustracja I. Wspólna fotografia członkiń Koła, wykonana 14 kwietnia 1933 r. Od lewej: Rachela z Eszwowiczów Eszwowiczowa (1894-1970) - żona mistrza budowlanego Leona, Salomea z Samuelowiczów Abrahamowiczowa (1884-1971), Sabina z Abrahamowiczów Leonowiczowa (1884-1939) - żona konduktora kolejowego Zachariasza, Domicela (Dewora) z Samuelowiczów Eszwowiczowa (1889-1940), Rebeka (Lina) z Abrahamowiczów Szulimowiczowa (1906-1987), Minka (Maria) z Szulimowiczów Ickowiczowa (1906-1973) - żona maszynisty kolejowego Samuela, członka Związku Młodzieży Karaimskiej „Odrodzenie”, który trzyma tabliczkę z nazwą Koła i datą, Sabina z Samuelowiczów Nowachowiczowa (1885-1960) - prezeska Koła, pochodząca z Trok Nina z Abkowiczów Mortkowiczowa (1901-1990), Janina z Szulimowiczów Zarachowiczowa (1900-1984) - żona ribbi Zaracha Zarachowicza, Helena z Nowachowiczów Leonowiczowa (1890-1967) - żona członka Zarządu Gminy, Ezuy Leonowicza, gospodarza w Załukwi, Helena z Ickowiczów Sulimowiczowa (1891-1950) - żona Leona, maszynisty kolejowego, członka Zarządu Gminy, pochodzącą z Łucka Zofia z Nowickich Eszwowiczowa (1892-1968). 


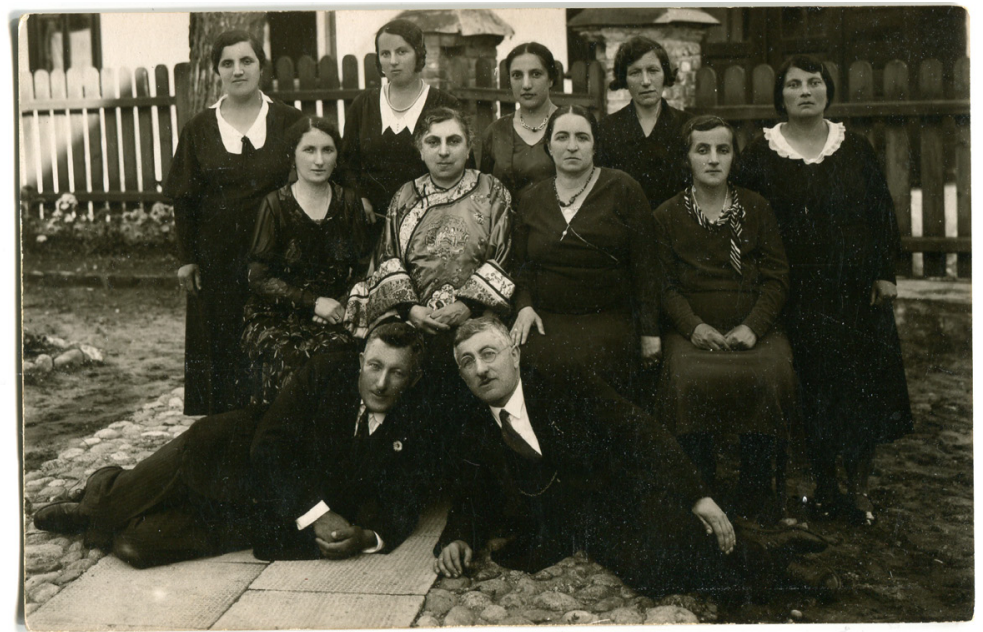

Ilustracja 2. Wizyta halickiego Koła Pań w Wilnie, lipiec 1933 r. Od lewej stoją: Lina z Mordkowiczów Ickowiczowa (1901-1991), Mina (Maria) z Szulimowiczów Ickowiczowa, Rebeka (Lina) z Abrahamowiczów Szulimowiczowa, Domicela z Samuelowiczów Eszwowiczowa, Zofia z Nowickich Eszwowiczowa; siedzą: Janina z Szulimowiczów Zarachowiczowa, Wiera Szapszałowa, Sabina Nowachowiczowa, Helena z Ickowiczów Sulimowiczowa; u dołu: Leon Sulimowicz i Leon Eszwowicz.

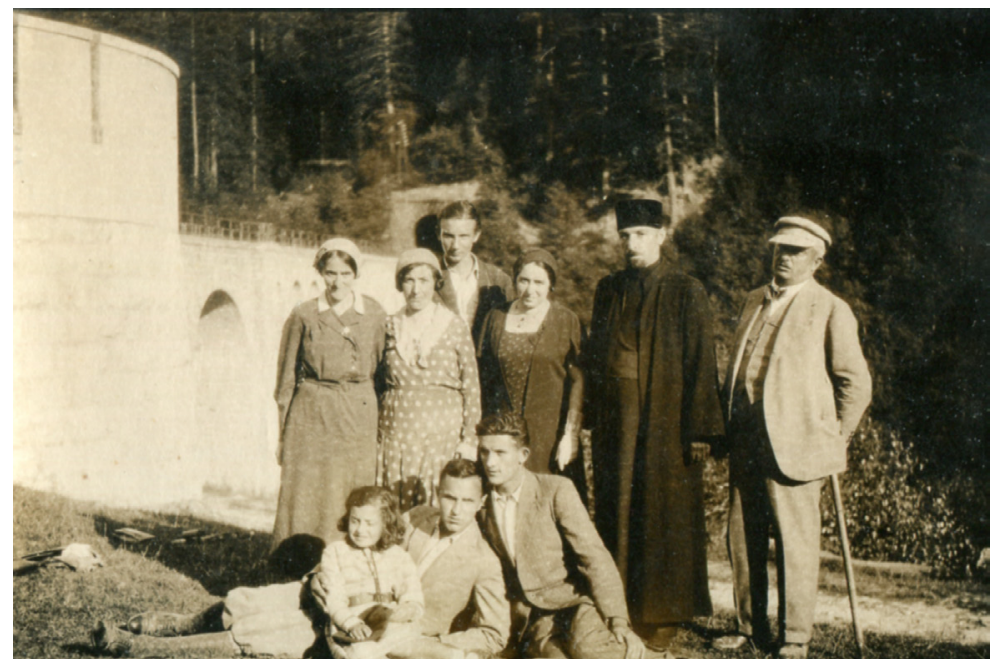

Ilustracja 3. Wycieczka w Karpaty podczas wizyty ułf hazzana Szymona Firkowicza w Haliczu, Jaremcze, 17 sierpnia 1933 r. Od lewej: Helena z Nowachowiczów 
Leonowiczowa, Anna z Nowachowiczów Ickowiczowa, Stanisław Strycharski (syn Zofii z Mordkowiczów), Sabina Nowachowiczowa, Szymon Firkowicz, Ezua Leonowicz; u dołu: Amalia Leonowicz (córka Heleny i Leona), Józef Szulimowicz, Józef Sulimowicz.

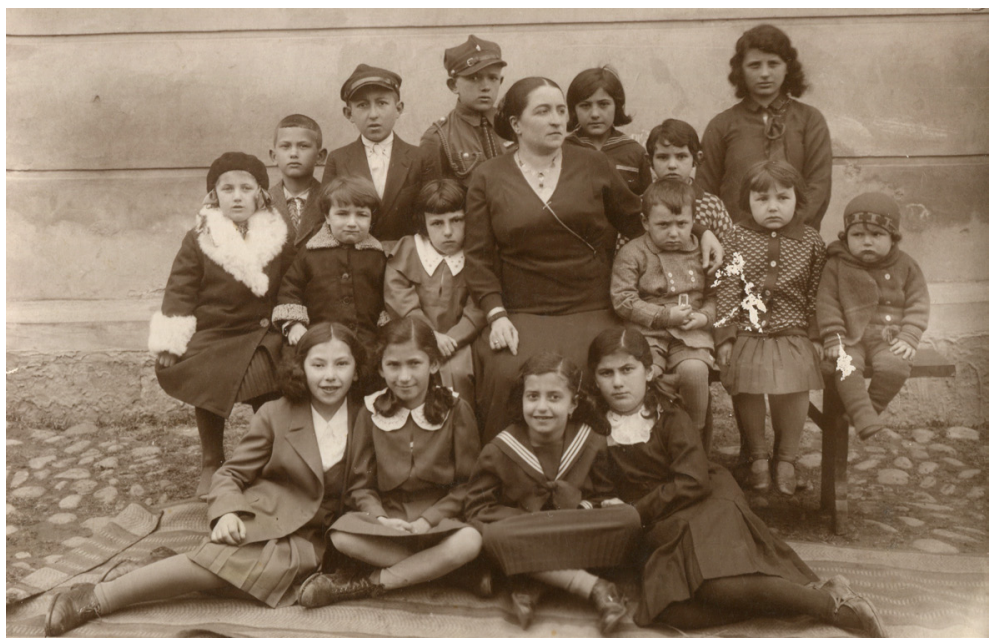

Ilustracja 4. Sabina Nowachowiczowa z dziećmi, ok. 1933 r.

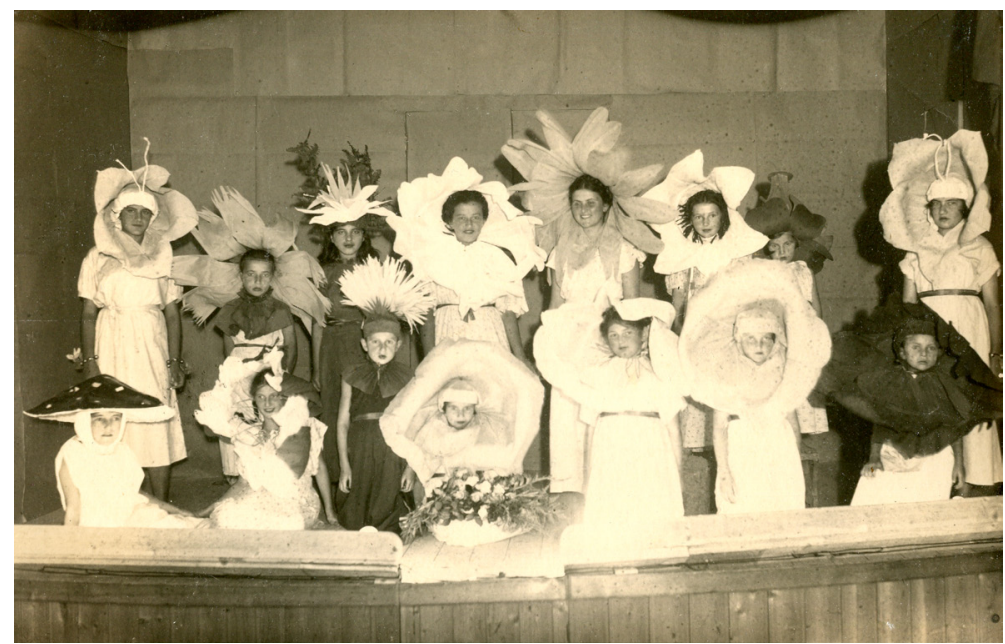

Ilustracja 5. Przedstawienie karaimskiego teatrzyku dziecięcego, sierpień 1938 r. 


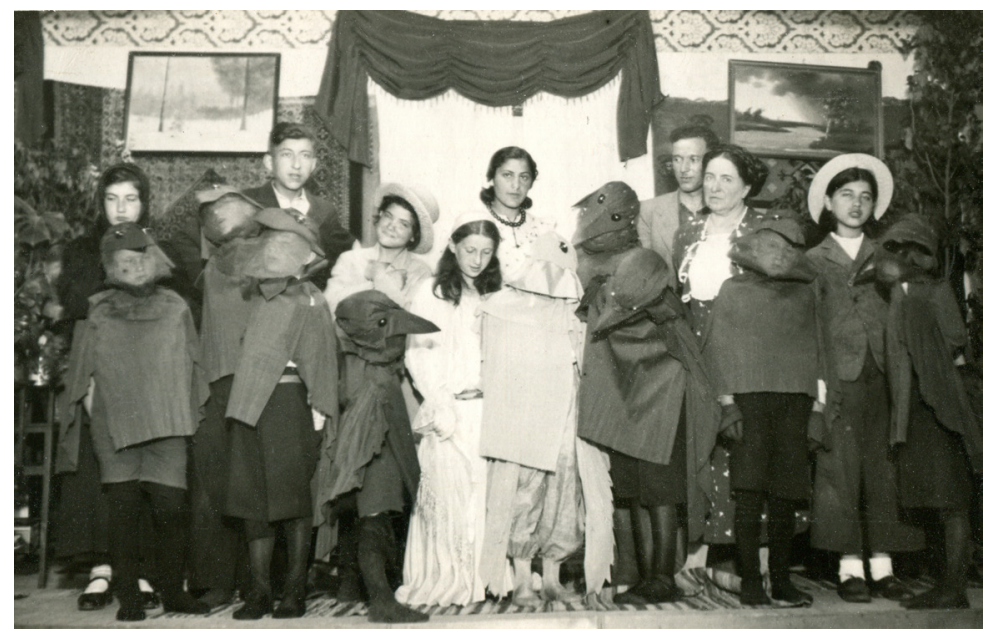

Ilustracja 6. Przedstawienie karaimskiego teatrzyku dziecięcego. Lata 30. XX w.

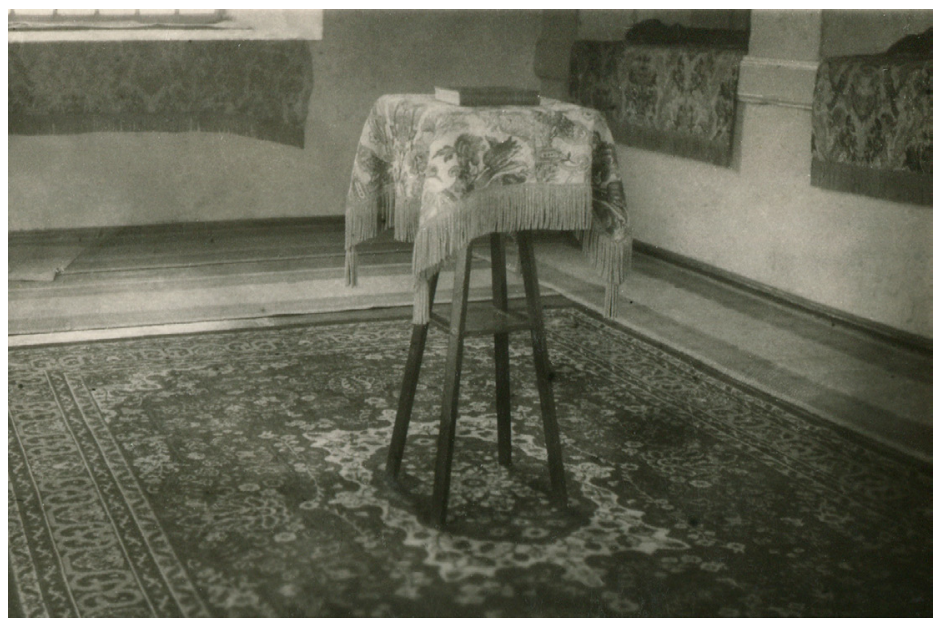

Ilustracja 7. Ufundowane przez członkinie Kola Pań kapy i pokrowce w galerii dla kobiet kienesy w Haliczu, 1934 r. Zdjęcie wykonane przez Marka Sulimowicza i ofiarowane matce, Helenie, z dedykacją: „Kochanej Mamie, członkini «Koła Pań Karaimskich» w Haliczu”. 